Kemudi: Jurnal Ilmu Pemerintahan | 179

Volume 05 Nomor 02 Februari 2021

2622-9633 (Online)

Open Access at: https://ojs.umrah.ac.id/index.php/kemudi

DOI: https://doi.org/10.31629/kemudi.v5i02.3104

\title{
Inovasi Pelayanan Berbasis Electronic Government Melalui Aplikasi Pendaftaran Antrian Paspor Online (Apapo) Di Kantor Imigrasi Kelas I Tanjungpinang Tahun 2019
}

\author{
Handrisal \\ Dosen Program Studi Ilmu Pemerintahan \\ Universitas Maritim Raja Ali Haji \\ Handrisal.88@umrah.ac.id \\ Nazaki \\ Dosen Program Studi IImu Pemerintahan \\ Universitas Maritim Raja Ali Haji \\ nazaki@umrah.ac.id \\ Muhammad Hafiz \\ Mahasiswa Program Studi Ilmu Pemerintahan \\ Universitas Maritim Raja Ali Haji \\ Mhdhafiz0422@gmail.com
}

\begin{abstract}
ABSTRAK
Pesatnya perkembangan ilmu pengetahuan, teknologi serta transportasi telah memudahkan orang untuk melakukan perjalanan dari suatu negra ke negra lain. Keadaan tersebut mengakibatkan meningkatnya perjalanan antar negara yang dilakukan penduduk indonesia, sehingga masyrakat memerlukan paspor. Hal ini menyebabkan peningkatan jumlah pemohon paspor setiap tahunnya. Dengan peningkatan jumlah permohonan paspor tentu membutuhkan waktu antrian yang lama. Menyikapi hal tersebut, Direktorat Jendral imigrasi melakukan inovasi pelayanan pendaftaran paspor melalui aplikasi antrian permohonan paspor secara online (Apapo). Penelitian ini bertujuan untuk menganalisis keberhasilan inovasi pelayanan dengan menggunakan aplikasi APAPO pada kantor imigrasi kelas I tanjungpinang. Metode penelitian yang digunakan adalah metode penelitian deskriptif dengan pendekatan kualitatif. Teknik pengumpulan data dilakukan dengan cara wawancara, observasi dan dokumentasi terkait dengan antrian permohonan paspor secara online. Data yang didapat dianalisis secara kualitatif dengan menggunkan teori keberhasilan Inovasi menurut Rogers yang mengemukakan keberhaslan suatu inovasi dipengaruhi oleh beberapa indikator yaitu; karakteristik inovasi, saluran komunikasi, upaya perubahan dari agen, dan sistem sosial. Dari hasil penelitian, dapat ditarik kesimpulan, bahwa inovasi pelayanan melalui aplikasi Apapo pada kantor kelas imigrasi kelas I Tanjungpinang sudah cukup berhasil, namun dari empat faktor keberhasilan inovasi sebagaimana yang dikemukakn oleh Rogers Terdapat dua indikator yang belum maksimal yaitu saluran komunikasi dan upaya dari agen.
\end{abstract}

Kata Kunci: Inovasi, Pelayanan, Paspor 


\section{Pendahuluan}

Inovasi merupakan salah satu hal yang harus selalu dilakukan untuk mengembangkan organisasi menjadi lebih baik, tidak terkecuali pada organisasi non profit seperti pemerintah. Maka dari itu organisasi dituntut untuk selalu memiliki inovasi tinggi untuk mengembangkan organisasi menjadi lebih baik dari sebelumnya. Di sisi lain, perkembangan masyarakat yang sangat dinamis juga memerlukan responsivitas atau kepekaan terhadap pemenuhan kebutuhan serta tuntutan masyarakat akan pelayanan yang lebih baik. salah satu hal yang dapat dilakukan untuk memberikan pelayanan yang lebih baik kepada masyarakat adalah melalui inovasi pelayanan.

Dalam perkembangannya, inovasi bahkan diyakini sebagai keharusan bagi setiap organisasi pemerintah yang bersentuhan langsung dengan pelayanan kepada masyarakat. Seperti halnya inovasi pelayanan pendaftaran paspor Pada kantor Imigrasi melalui Sisitem Aplikasi Pendaftaran Antrian Paspor Online (APAPO). Aplikasi ini dikeluarkan dalam rangka memperbaiki sistem pelayanan paspor agar lebih baik. Selama ini seperti diketahui bahwa antrean permohonan paspor selalu menumpuk sehingga seringkali memakan waktu yang lama dalam pengurusannya.

Sejak diluncurkan pada bulan agustus, applikasi layanan paspor online yang bisa di download secara gratis melalui layanan google play store/App store ini sudah di download oleh 1 juta lebih pengguna di seluruh Indonesia. Pemberlakuannya di seluruh Indonesia didasari oleh Surat Edaran Direktur Jenderal Imigrasi No IMI-UM,01.01-4166 tahun 2017 tentang Implementasi Aplikasi Pendaftaran Antrian Permohonan Paspor Secara Online (APAPO) diseluruh Indonesia. 
Dengan diterapkannya sistem APAPO ini, diharapkan mampu memenuhi kebutuhan dan tuntutan masyarakat dalam peningkatan percepatan pelayanan publik dalam pengurusan paspor terutama dalam hal antrian, namun dalam hal implementasi sistem APAPO ini pada Kantor Imigrasi Kelas I Tanjungpinang masih ditemukan beberapa permasalahan yang menjadi penghambat dalam mempercepat dan mempermudah proses pelayanan paspor. Permasalahan tersebut di antaranya adalah:

1. Kurang optimalnya sistem layanan online, seperti masih ditemukan laman website yang tidak bisa dijangkau (error) pada saat pelacakan informasi tentang sistem APAPO.

2. Masih ada masyarakat Kota Tanjungpinang yang belum mengetahui adanya layanan paspor online ini. Sehingga calon pemohon pembuat paspor yang sudah sampai di kanotr imigrasi kelas I Tanjungpiang untuk mendapatkan layanan harus melakukan pendaftaran terlebih dahulu melalui aplikasi yang telah disediakan supaya mendapatkan nomor antrian.

Berdasarkan uraian di atas, penelitian ini bertujuan untuk menganalisis

keberhasilan Inovasi Pelayanan Berbasis Electronic Government Melalui Aplikasi Pendaftaran Antrian Paspor Online (Apapo) Di Kantor Imigrasi Kelas I Tanjungpinang Tahun 2019.

\section{Tinjauan Pustaka}

Penelitian terhadap pemberlakuan sistem APAPO ini sudah pernah dilakukan oleh (Chaharani, Adi, and Hasmi 2020), hasil peneltian menunjukkan bahwa dengan adanya aplikasi paspor online APAPO, proses pembuatan paspor saat ini menjadi lebih mudah, murah, dan cepat. Hal ini dikarenakan pemohon dapat mengurusnya sendiri tanpa bantuan dari orangorang yang dengan sengaja mengambil keuntungan sendiri (dalam hal ini calo-calo yang banyak berkeliaran di sekitar lingkungan kantor imigrasi ataupun birojasa), dan itu merupakan salah satu bentuk nyata dari berkembangnya e-goverment khususnya dibidang pelayanan publik yang secara langsung dapat dirasakan oleh warga negara khususnya di wilayah Malang. 
Penelitian lainnya tentang pemberlakuan sistem APAPo juga dilakukan oleh (Ayutasya, Purwanti, and Amirulloh 2020), berbeda dengan sebelumnya penelitian ini menggunakan pendekatan kuantitatif yang temuan penelitiannya menunjukkan bahwa aplikasi pendaftaran antrian permohonan paspor online (APAPO) memberikan pengaruh positif terhadap efektivitas layanan pembuatan paspor.

Jika dikaitkan dengan inovasi pelayanan yang memanfaatkan tekonlogi informasi, peneltian mengenai hal tersebut juga telah dilakukan oleh (Wilonotomo, and Koesmoyo Ponco Aji 2018), dalam temuan penelitiannya diketahui bahwa Penggunaan teknologi informasi dalam pelayanan paspor sangat membantu meningkatkan efektifitas maupun efisiensi pekerjaan, selain itu penggunaan teknologi informasi juga mampu meningkatkan keamanan terhadap suatu keabsahan dokumen.

Penelitian lainnya yang dilakukan oleh (Suryani and Yuliani 2020) menemukan bahwa sebelum diberlakukannya sistem APAPO dalam pengurusan paspor, masyarakat Provinsi Bengkulu sering mengalami kendala-kendala antara lain:

1. Prosedur yang rumit

2. Tidak adanya transparansi biaya

3. Masih ditemukan praktek pungutan liar yang tidak sesuai dengan ketentuan.

4. Praktek percaloan.

Namun dengan adanya penerapan Aplikasi APAPO yang merupakan terobosan baru atau perubahan baru telah memberikan keuntungan dan menjadi alternative dalam rangka memenuhi kebutuhan masyarakat khususnya masyarakat provinsi Bengkulu dalam pengurusan paspor.

Berbeda dengan penelitan-penelitian sebelumnya sebagaimana yang telah diuraikan, penelitan ini pada dasarnya juga meneliti tentang Aplikasi 
APAPO pada Kantor Imigrasi, namun pada penelitian ini yang menjadi focus penelitian adalah mengenai keberhasilan dari penerapan inovasi pelayanan berbasis electronic government berupa pemanfaatan Aplikasi APAPO pada pelayanan paspor di Kantor Imigrasi Kelas I Tanjungpinang.

Secara konsep, inovasi dapat diartikan sebagai transformasi pengetahuan kepada produk, proses dan jasa baru, tindakan menggunakan sesuatu yang baru, sedangkan menurut mitra pada buku tersebut dan pada haalaman yang sama, bahwa inovasi merupakan eksploitasi yang berhasil dari suatu gagasan baru atau dengan kata lain mobilisasi pengetahuan, keterampilan teknologis dan pengalaman untuk menciptakan produk, proses dan jasa baru (Rosenfeld dalam Sutarno 2012).

Dalam bahasa undang-undang, inovasi adalah suatu kegiatan penelitian, pengembangan, dan atau perekayasaan yang dilakukan untuk pengembangan penerapan praktis nilai dan konteks ilmu pengetahuan yang baru, ataupun cara baru untuk menerapkan ilmu pengetahuan dan teknologi yang sudah ada ke dalam produk ataupun proses produksinya (Undang-Undang Nomor 18 Tahun 2002)

Di sisi lain, (Susanto 2010) memberikan definisi bahwa inovasi memiliki pengertian yang tidak hanya sebatas membangun dan memperbaharui namun juga dapat didefinisikan secara luas, memanfaatkan ide-ide baru untuk menciptakan produk, proses, dan layanan, sedangkan menurut Menurut (Said 2007) mengartikan inovasi sebagai perubahan yang terencana dengan memperkenalkan teknologi dan penggunaan peralatan baru dalam lingkup kerja di instansi.

Menurut Asian Development Bank (dalam Sentosa 2019) inovasi adalah sesuatu yang baru, dapat di implementasikan, dan memiliki dampak yang 
menguntungkan. Inovasi bukan sebuah kejadian ataupun aktivitas, inovasi adalah konsep, proses, penerapan, dan kapabilitas yang menentukan kesuksesan organisasi. Inovasi dapat membantu sektor publik untuk membuat nilai untuk masyarakat. Inovasi dilakukan karena ada tujuan tertentu yang ingin dicapai oleh manusia. Adapun tujuan inovasi adalah sebagai berikut :

1. Meningkatkan kualitas

2. Mengurangi biaya.

3. Menciptakan pasar baru.

4. Memperluas jangkauan produk.

5. Mengganti produk/layanan.

6. Mengurangi konsumsi energi.

Jika dikaitkan dengan konteks pelayanan publik, inovasi bisa diartikan sebagai prestasi dalam meraih, meningkatkan, dan memperbaiki efektivitas, efisiensi dan akuntabilitas pelayanan publik yang dihasilkan oleh inisiatif pendekatan, metodologi, dan atau alat baru dalam pelayanan masyarakat (Mirnasari and Suaedi 2013). Lebih lanjut, (Delafrooz, Taleghani, and Taghineghad 2013) mengartikaninovasi layanan adalah kegiatan baru yang dilakukan perusahaan yang menghasilkan layanan baru prosedur baru atau proses dari meningkatkan nilai tambah bagi jasa yang diberikan perusahaan. Dengan adanya inovasi yang dilakukan perusahaan akan meningkatkan kinerja dari perusahaan.

Inovasi layanan pada dasarnya merupakan upaya untuk mengahdirkan produk layanan baru untuk meningkatkan kualitas pelayanan hal ini sebagaimana dikemukakan oleh (Paul Windrrum dalam Hutagalung and Hermawan 2018) yang menyatakan bahwa inovasi layanan menghadirkan suatu produk layanan baru atau sebuah bentuk peningkatan kualitas produk layanan yang sydah ada, termasuk juga yang mengubah karakteristik produk layanan ataupun desain layanan itu sendiri. Dari pengertian diatas dapat 
disimpulkan inovasi layanan adalah kegiatan pembaharuan yang dilakukan perusahaan untuk meningkatkan layanan serta mengahasilkan layanan baru. Sebagai sebuah produk layanan yang baru, inovasi pelayanan dalam implementasinya bisa saja mengalami keberhasilan ataupun sebaliknya justru mengalami kendala, hambatan, bahkan sampai pada kegagalan. keberhasilan ataupun kegagalan suatu inovasi menurut (Rogers dalam Hutagalung and Hermawan 2018) akan ditentukan oleh hal-hal sebagai berikut:

a. Karakteristik inovasi (produk)

Sebuah produk baru dapat dengan mudah diterima oleh konsumen (masyarakat) jika produk tersebut mempunyai keunggulan relatif artinya produk baru akan menarik konsumen jika produk tersebut mempunyai kelebihan dibandingkan produk-produk yang sudah ada sebelumnya.

b. Saluran komunikasi (kesesuaian)

Inovasi akan menyebar pada konsumen yang ada di masyarakat melalui saluran komuikasi yang ada. suatu produk baru akan dapat dengan segera dan dengan segera menyebar luas ke masyarakat (konsumen) jika perusahaan memanfaatkan saluran komunikasi yang banyak dan jangkauan luas seprti media masa dan jarian interpersonal

c. Upaya perubahan dari agen

Perusahaan harus mampu mengindentifikasi secara tepat opinion leader yang akan digunakan dan mampu melibatkannya sebagai agen perusahaan untuk mempunyai konsumen atau masyarakat dalam menerima dan menggunakan produk baru (inovasi).

d. Sistem sosial

Pada umumnya sistem sosial masyarakat modren leih mudah menerima inovasi dibandingkan dengan masyarakat yang berorientasi pada sisitem sosial 
tradisional karena masyarakat modren cendrung mempunyai sikap positif terhadap perubahan, umumnya menghargai terhadap pendidikan dan ilmu pengetahuan, mempunyai perspektif keluar yang lebih baik dan mudah berinteraksi dengan orang-orang di luar kelompoknya, sehingga mempermudahmasukan penerima ide ide baru dalam sistem sosial.

\section{Metode Penelitian}

Penelitian ini merupakan jenis penelitian Deskriptif kualitatif. Metode penelitian kualitatif ini menurut (Sugiyono 2010) sering disebut metode penelitian naturalistik karena penelitiannya dilakukan pada kondisi yang alamiah (natural setting) disebut juga sebagai metode etnographi, karena pada awalnya metode ini lebih banyak digunakan untuk penelitian bidang antropologi budaya, disebut sebagai metode kualitatif, karena data yang terkumpul dan analisisnya lebih bersifat kualitatif. Jenis pendekatan kualitatif ini dipilih agar dapat menggambarkan realitas kondisi penerapan inovasi pelayanan melalui sistem aplikasi pendaftaran antrean paspor online (APAPO) di kantor Imigrasi Kelas I Tanjungpinang.

Informan yang dilibatkan dalam penelitian ini terdiri dari Kepala seksi teknologi infomasi dan komunikasi Kantor Imigrasi Kelas I Tanjungpinang, Pegawai Kantor Imigrasi Kelas I Tanjungpinang, dan Masyarakat yang menjadi pemohon pembuatan paspor yang menggunakan Aplikasi APAPO.

\section{Pembahasan}

Dengan menggunakan 4 (empat) dimensi penelitian yaitu karakteristik inovasi, saluran komunikasi, upaya perubahan dari agen, dan sisitem sosial untuk mengukur sejauh mana keberhasilan inovasi pelayanan antrian paspor dengan menggunakan aplikasi Apapo pada Kantor Imigrasi Kelas I Tanjungpinang maka ditemukan hasil sebagai berikut:

a. Karakteristik Inovasi 
Karakteristik Inovasi adalah Sebuah produk baru dapat dengan mudah diterima oleh masyarakat, jika produk tersebut mempunyai keunggulan relatif artinya produk baru akan menarik konsumen, dan produk tersebut mempunyai kelebihan dibandingkan produk-produk yang sudah ada sebelumnya. Tingkat keunggulan relatif pada suatu inovasi dapat diukur berdasarkan nilai kesenangan dan kepuasan dalam keberhasilan inovasi.

Tabel 1

Perbedaan Pendaftran Paspor Secara Offline dan Online (APAPO)

\begin{tabular}{|c|l|l|}
\hline NO & \multicolumn{1}{|c|}{ SECARA OFLINE } & \multicolumn{1}{c|}{ SECARA ONLINE (APAPO) } \\
\hline 1 & $\begin{array}{l}\text { Datang ke imigrasi untuk } \\
\text { mendaftar }\end{array}$ & $\begin{array}{l}\text { Download aplikasi APAPO di play } \\
\text { store }\end{array}$ \\
\hline 2 & $\begin{array}{l}\text { Mengisi semua fromulir } \\
\text { pembuatan paspor }\end{array}$ & $\begin{array}{l}\text { Login dengan memasukkan NIK, } \\
\text { Nama lengkap, TTL,No Hp, hingga } \\
\text { Alamat sesuai Ktp }\end{array}$ \\
\hline 3 & $\begin{array}{l}\text { Masukan semua berkas asli } \\
\text { untuk di verifikasi }\end{array}$ & Pilih jadwal foto pagi/siang \\
\hline 4 & $\begin{array}{l}\text { Menunggu jadwal antrian foto } \\
\text { Kemabali ke kantor imigrasi } \\
\text { dengan tanggal ditentukan dan } \\
\text { mengambil nomor antrian }\end{array}$ & Print kode/QR code \\
dipilih untuk pengurusan paspor \\
\hline
\end{tabular}

Sumber : Data Olahan Penelitian

Perbedaan antara alur pendaftaran online dan offline yakni dalam perbedaan waktu dimana pada pendaftara secara online terlihat jelas kepastian waktu yang diberikan karena pendaftar diberi kemudahan untuk melakukan pendaftara melalui aplikasi yaitu aplikasi Apapo dengan cara mengunduh aplikasi Apapo di Play Store secara gratis, pendaftar dimudahkan dengan cara bisa mendaftar dirumah dan tidak perlu lagi mengantri dikantor pelayanan imigrasi, karena dengan pendaftaran melalui aplikasi Apapo ini pendaftar sudah mendapatkan nomor antrian langsung dan juga mengetahu waktu antrian jika pendaftaran yang dilakukan telah berhasil dan mendapatkan QR Code atau kode booking Apapo. Untuk meminimalisis ramainya yang mendaftar melalui aplikasi apapo, pendaftara secara online memiliki batasan kuota pendaftar setiap harinya yakni 50 orang dalam sehari. Dan aplikasi apapo ini sudah di download oleh 1 jt lebih yang memakai aplikasi tersebut, dapat dilihat dengan pengunduhan aplikasi Apapo di playstore.

Berbeda dengan pendaftaran yang dilakukan secara offline dimana pendaftaran secara offline ini tergantung dengan jumlah yang mendaftar dalam 
perharinya, untuk kepastian waktu dalam pendaftaran ofline ini dilakukan secara tentatif tergantung dengan jumlah yang mendaftar di imigrasi.

Inovasi berupa aplikasi pendaftran antrian paspor online bertujuan untuk memberikan kepastian pelayanan yang tercepat dan terdepan atas setiap kendala. Keberadaan apapo ini di perlukan sebagai upaya kepastian waktu dalam pembuatan paspor terutama bagi masyrakat yang terkendala sarana transpostasi karena tidak memiliki kendaraan dan sibuk dengan kegiatan pekerjaaan. Hal ini disampaikan oleh bapak Rino Dwilukito,S.H selaku kepala sub seksi teknologi informasi keimigrasian menyatakan bahwa:

"inovasi yang dilakukan kantor imigrasi dalam pelayanan pembuatan paspor yaitu apapo, apapo ini adalah sebagai bentuk kepastian pelayanan untuk masyaarakat, agar masyarakat tau tentang kapan harus datang ke kantor untuk pembuatan paspor , jadi masyrakat tidak perlu mengantri lagi dan banyak kelebihan dengan adanya aplikasi apapo ini salah satunya mengurangi percaloan"

Sistem layanan antrean online dengan sistem kouta dan waktu bedasarkan edaran dirjen imigrasi diharapkan tidak ada lagi pengurusan paspor yang dilakukan dengan cara calo, karana ada beberapa masyrakat yang ingin membuat paspor tetapi tidak mau menunggu antrian dan membutuhkan waktu yang lama untuk membuat paspor, hal ini lah yang menyebabkan masyarakat membutuhkan calo untuk pembuatan paspor, maka dari itu tidak ada lagi masyarakat yang menggunakan calo dalam pembuatan paspor, $\mathrm{Hal}$ ini disampaikan oleh bapak Rino Dwilukito,S.H selaku kepala sub seksi teknologi informasi keimigrasian menyatakan bahwa :

"kalau malasah calo saya juga kurang tahu berapa banyak yang ada di sini,tetapi jika pegawai imigrasi tebukti melakukan calo, kepala kantor imigrasi tidak segan mengambil tindakan tegas. Maka dari ini untuk menghindari percaloan dibuatlah aplikasi antrian online ini"

Pemohon dapat mengakses melalui aplikasi ataupun website untuk mendaftar antrian permohonan paspor secara online. Pemohon dengan bebas dapat memilih waktu yang diinginkan untuk datang secara langsung ke kantor imigrasi kelas I tanjungpinang. Waktu yang disediakan oleh pihak kantor imigrasi ialah mulai hari senin hingga hari jumat pada waktu jam kerja yaitu dari pukul 08.00 wib pagi hingga pukul 15.00 wib sore. Dengan begitu bagi pemohon yang memiliki jadwal kerja yang padat dapat menyisihkan waktunya untuk datang ke kantor imigrasi sehingga tidak mengganggu jam kerja dari pemohon tersebut. 
Selain itu menurut masyarakat bapak ismail, mengemukakan mengenai karakteristik dari inovasi pelayanan apapo ini sebagai berikut :

"inovasi dalam pelayanan kantor imigrasi sangat lah baik, dan berbeda dengan yang sebelumnya, kepastian waktunya dalam pembuatan paspor, tanpa kita kekantor kita juga bisa mengisi data-data keperluan untuk pembuatan paspor di rumah atau tempat kerja ini juga salah satu untuk mempermudah saya atau masyarakat yang lain dalam pembuatan paspor, tetapi kouta yang diberi oleh kantor imigrasi hanya sedikit, sehingga ketika kita memilih tanggal kouta sudah habis"

Hal ini dipertegas kembali oleh Ibu Sondang,amd selaku Cs imigrasi bagian pelayanan, mengemukakan mengenai karakteristik dari inovasi pelayanan apapo ini sebagai berikut :

"Dengan adanya APAPO ini masyrakat bisa bebas mendaftar secara online dan bisa mengatur waktu sendiri kapan datang ke Kantor Imigrasi sehingga tidak perlu repot menunggu antrean di kantor. Tentu disamping itu dibatasi jumlah kuotanya, jadi mereka memilih jam berapa bisa datang ke Kantor Imigrasi berdasarkan permohonannya waktu online."(wawancara,9 september 2020)

Pemohon dapat mengakses pendaftaran antrian permohonan paspor secara online kapan saja sesuai waktu jam kerja dan dimana saja. Namun pemohon tidak dapat dipastikan apabila ingin mendaftar hari ini, maka akan segera dapat mendaftar hari ini juga. Hal tersebut karena adanya batasan kouta yang diberikan setiap harinya hanya 50 penerbitan paspor. sehingga tidak ada penumpukan yang mengantri dalam pembuatan paspor, namun hal ini sering dikeluhkan masyrakat yang ingin membuat paspor.

Hal ini dipertegas kembali oleh Ibu Sondang,amd selaku Cs imigrasi bagian pelayanan, mengemukakan mengenai karakteristik dari inovasi pelayanan apapo ini sebagai berikut:

"untuk jumlah kouta yang di sediakan oleh kantor imgrasi hanya 50 penerbitan paspor, kalau dilihat banyaknya sama aja sih dek, kalau pagi biasanya banyak masyarakat umum, kalau siang biasnya ramai orang yang kerja dek"(wawancara,18 november 2020)

Adanya antrian permohonan paspor secara online bagi masyarakat pemohon sangat membantu dan mempermudah dengan tidak membutuhkan waktu yang lama untuk mengantri, dengan menunjukan barcode dapat lansung menuju customer service. Sehingga adanya antrian permohonan paspor secara online merupakan jawaban atas kebutuhan masyrakat. dengan semakin majunya zaman, penyelenggara pelayanan publik dituntut untuk mengikuti kemajuan teknologi dan kemajuan zaman. 
Berdasarkan uraian di atas menujukan bahwa karakteristik inovasi pelayanan melalui aplikasi APAPO ini sebagai salah satu inovasi pelayanan publik yang dilakukan oleh kantor imigrasi kelas I tanjungpinang guna mempermudah masyrakat dalam pembuatan paspor. Sehingga memberikan layanan paspor yang jelas terhadap kepastian waktu, dan didukung pemerintah dalam memberikan layanan pembuatan paspor terhadap masyarakat.

\section{b. Saluran Komunikasi}

Komunikasi adalah faktor yang paling penting dari sebuah organisasi supaya program-program dapat di realisasikan sesuai dengan maksud dan tujuan, Saluran komunikasi sangat penting untuk keberhasilan inovasi karena saluran komunikasi ini untuk menyampaikan pesan. Pesan yang dimaksud bisa dalam bentuk tatap muka dan media masa. Kantor imigrasi telah memberikan saluran komunikasi melalui berbagi macam media yaitu media masa dan media sosial, saluran komunikasi ini dilakukan untuk memberitahukan kepada masyrakat bahwa adanya inovasi baru yaitu aplikasi apapo untuk memudahkan masyarakat dalam pembuatan paspor. Hal ini disampaikan oleh Bapak Rino Dwilukito,S.H selaku kepala sub seksi teknologi informasi keimigrasian menyatakan bahwa :
"pengenalan aplikasi ini dikalangan masyarakat kalau dalam sosialisasi, kami dari pihak kanim belum ada mensosialisasikan ke masyarakat lansung untuk memberitahukan penjelasan aplikasi apapo ini, tetapi kalau kalangan instansi seperti dinas pariwisata, bank-bank dan instansi-intansi yang memungkinkan untuk berlibur perjlanan yang diharuskan untuk membuat paspor sudah kami sosialisasikan,untuk media kami mengunakan media massa dan media sosial, seperti radio di RRI kami mengumumkan tentang aplikasi ini 2 minggu dalam sebulan tepatnya jam 08.00 wib, sedangkan media sosial ada instagram, facebook, dan line untuk melihat bagaimana cara penggunaan aplikasi tersebut".

Hal serupa juga kembali ditanyakan kepada pegawai kanim ibu faiza selaku bagian pelayanan pembuatan paspor :

"pengenalan aplikasi apapo ini saya rasa sudah banyak yang mengetahuinya, karna di kantor imigrasi kelas 1 tanjungpinang sudah ada media sosial seperti instagram, facebook bahkan cara cara untuk menggunakan apapo sudah kami upload" (Wawancara, 9 september 2020)

Dalam mengurus paspor juga melalui tahap wawancara kepada yang membuat paspor untuk mengetahui data yang vailid, yang menggunakan 
APAPO ini kebanyakan untuk kepentingan liburan. Untuk itu makin meningkat saluran komunikasi tentang APAPO ini makin meningkat pula masyarakat mengetahui tentang pembuatan paspor online,begitu pula sebaliknya. Selain itu seorarng masyrakat yang mengemukakan mengenai saluran komunikasi yaitu:

"kalau untuk sosialisasi saya kurang tahu ya dek, karna saya tahu aplikasi ini memamng bener-bener abang saya yang kasi tau dek, mungkin pihak kantor ada memberikan sosialisasi lewat media sosial, tapi untuk terjun kemasyrakat tentang aplikasi ini memang saya tidak mengetahuinya" (Wawancara, 9 september 2020)

Berdasarkan uraian diatas dapat diketahui bahwa Kantor Imigrasi Kelas I Tanjungpinang sudah memberikan sosialisasi aplikasi APAPO namun sosialisasi yang digunakan melalui media massa seperti radio, instagram, facebook, dan brosur. Sosialisasi yang diberikan kepada masyarakat, diharapkan agar masyrakat mengetahui tata cara penggunaan APAPO namun masih banyak masyarakat yang tidak menggunakan media masa, sehingga masyarakat tidak mengetahui adanya aplikasi APAPO. dari pihak kantor imigrasi jugaa belum pernah mensosialisasi secara tatap muka kepada masyrakat. Dengan demikian diketahui bahwa inovasi pelayanan melalui aplikasi antrian paspor online belum sepenuhnya menjalankan sosialisasi kepada masyrakat tentang penggunaan aplikasi apapo ini.

\section{c. Upaya Dari Agen}

Upaya dari dari agen merupakan salah satu dimensi keberhasilan inovasi karena upaya dari kantor imigrasi dalam meningkatkan pelayan dan memberikan sesuatu hal yang baru kepada masyrakat. Berdasarkan Surat Edaran Direktur Jendral Imigrasi Nomor IMI-UM.01.01-4166 tentang Implementasi Aplikasi Pendaftaran Antrian Paspor Online di seluruh Indonesia merupakan upaya peningkatan kualitas pelayanan keimigrasian baik bagi warga negara Indonesia maupun orang asing. Maksud dan tujuan dari surat edaran tersebut adalah memberikan kejelasan, ketertiban dan kepastian dalam pelaksanaan pendaftaran antrian permohonan penerbitan paspor secara online, dengan demikian kantor imigrasi harus mampu mengindentifikasi secara tepat opinion leader yang akan digunakan dan mampu untuk menghibau masyarakat dalam menerima dan menggunakan aplikasi apapo ini, sebagaimana dijelaskan 
oleh Bapak Rino Dwilukito,S.H selaku kepala sub seksi teknologi menyatakan bahwa:

"upaya dari kami sendiri melakukan banyak hal upaya, salah satunya dengan baliho yang tertera pada kantor imigrasi itu merupakan cara kami untuk memberitahukan masyarakat untuk mendaftrakan melalui aplikasi dan kami juga menyediakan Costumers service untuk membantu dalam penggunaan aplikasi tersebut. Kalau berbicara tentang arus pelayanan sama seperti biasanya akan tapi dengan adanya aplikasi apapo ini mempersingkat waktu dan memastikan waktu, jadi tidak perlu lagi antri berjam - jam bahkan sampai dilanjutkan besok."

Hal serupa juga kembali ditanyakan kepada pegawai kanim ibu Sondang.Amd selaku bagian pelayanan pembuatan paspor :

"kalau berbicara upaya, Jika masyarakat yang belum mendaftar online kami selaku bagian cs membimbing masyrakat agar mendownload aplikasi apapo tersebut agar masyrakat tau bahwa pendaftran tidak lagi ofline. Dan kami juga memberikan brosur tententang cara penggunaan apapo ini."

Berdasarkan wawancara di atas bahwa upaya perubahan dalam memberikan inovasi pelayanan untuk masyarakat dilaksanakan dengan semestinya dikarenakan sangatlah penting bagi masyarakat yang terkendala pada pada saat mengakses aplikasi tersebut. Kemudian penulis kembali melakukan dengan melakuan wawancara dengan ibu sondang selaku custumers service mengatakan bahwa :

"Kendala masyrakat kebanyakan masalah adalah jaringan, sehingga kami suruh mendaftar di rumah agar jaringan bagus saat mendftar pembuatan paspor, kadang ada juga pada saat mendaftar nomor nik dan kk tidak terbaca, maka dari itu kami menyuruh masyrakat agar ke disdukcapil untuk menginformasikan bahwa nomor Kk dan KTP sudah terdaftar di kantor disdukcapil dan untuk kouta pendaftran disediakan hanya 50 kouta".

Selanjutnya wawancara kepada informan bapak ismail selaku masyrakat yang menggunakan aplikasi apapo ini mengatakan bahwa :

"kendala saya pas mendaftar kemarin, jaringan saya lelet dan saat saya pilih jadwal kouta sudah penuh jadi baru sekarang saya daftar lagi di kantor imigrasi mumpung korona jadi sepi yang membuat paspor, jadi saya di sini aja isinya biar tidak terjadi kesalahan" (Wawancara, 9 september 2020)

Hal serupa juga kembali ditanyakan oleh ibu sondang selaku masyarakat yang menggunakan aplikasi apapo ini mengatakan bahwa :

"kendala saya saat mendaftar, masalah jaringan saya aja sih dek, muter -muter sehingga lama untuk mendaftarnya, dan pada saat 
mendaftar saya tidak kebagian waktu untuk pembuatan paspor katanya kouta sudah penuh"

Hal serupa juga kembali ditanyakan oleh otika ovino selaku masyarakat yang menggunakan aplikasi apapo ini mengatakan bahwa :

"kalau kandalanya kemarin saya minta tolong bantu temen untuk mengisi data di aplikasi tersebut dan saat memlih jadwal antrian paspor itu selalu full padahal sisa koutanya masih ada, saya pun kurang ngerti kesalahan saya dimana padhal saya udah coaba beberapa kali tapi tetap aja selalu full tapi akhirnya juga bisa saat di coba berulangkali".

Dalam upaya dari agen, peningkatan kualitas pelayanan keimigrasian baik kepada masyrakat dalam pembuatan paspor secara online, dengan adanya aplikasi Apapo ini mampu meningkatkan kinerja pemerintahan dan memperbaiki pelayanan publik secara efisien dan efektif. Penggunaan teknologi dalam pemerintah dengan masyarakat, swasta maupun pemerintah lainnya. Untuk itu diperlukan banyak persiapan termasuk menyiapkan sumber manusia yang berkualitas.

Sebagaimana dijelaskan oleh ibu faiza selaku pegawai pelayanan dalam pembuatan paspor menyatakan bahwa :

"kalau untuk bagian pelayanan paspor nya disini sudah lengkap, ada customer service, petugas input data, petugas wawancara dan rekam data biometrik, petugas adokasi paspor, petugas cetak paspor dan uji kualitas, petugas laminasi dan terakhir petugas serah paspor"

Tabel 2

Karakteristik Sumber Daya Manusia di Kantor Imigrasi Kelas I Kota Tanjungpinang

\begin{tabular}{|c|l|c|c|}
\hline No & \multicolumn{1}{|c|}{ Personil } & Volume (orang) & Kebutuhan \\
\hline 1 & Customer Service & 1 & D -3 \\
\hline 2 & Petugas Input Data & 2 & SMA dan S-1 \\
\hline 3 & $\begin{array}{l}\text { Petugas wawancara dan } \\
\text { Rekam Data Biometrik }\end{array}$ & 2 & D-3 \\
\hline 4 & Petugas Adokasi Paspor & 1 & SMA \\
\hline 5 & $\begin{array}{l}\text { Petugas Cetak Paspor dan Uji } \\
\text { Kualitas }\end{array}$ & 1 & SMA \\
\hline 6 & Petugas Laminasi & 1 & SMA \\
\hline 7 & Petugas Serah Paspor & 1 & \\
\hline
\end{tabular}

Sumber : Kantor Imigrasi Kelas I Kota Tanjungpinang, 2020

Demikian juga dengan halnya staf/pegawai merupakan sumber daya yang paling penting dalam melaksanakan kebijakan atau program. Kurangnya 
staf/pegawai pelaksana akan menghambat jalannya suatu kebijakan sehingga inovasi yang dilakukan tidak maksimal.

Sesuai dengan Surat Edaran Yang Dikeluarkan Oleh Kementrian Hukum Dan Ham Melalui Direktorat Jendral Imigrasi Yang Membuat Surat Edaran NO:IMIUM.01.01-4166 tentang implementasi aplikasi pendaftaran antrian permohonan paspor secara online seluruh indonesia. Semua Kantor imigrasi sudah menerapkan layanan daftar antrian paspor online khususnya pada Kantor Imigrasi Kelas I Tanjungpinang. Dengan mendaftar online ini, akan mendapatkan informasi lengkap kepastian hari dan jam untuk membuat paspor. Terlebih lagi, Satu akun bisa digunakan untuk mendapatkan 5 antrian paspor online. Berikut cara lengkapnya:

1. Buka website https://antrian.imigrasi.go.id/, buatlah akun baru atau login dengan akun Google Anda.

2. Opsi lainnya, Anda bisa download aplikasi Layanan Paspor Online di Google Play atau App Store. Buatlah akun baru dan login.

3. Setelah berhasil login, baik melalui website ataupun aplikasi, selanjutnya isi data yang diperlukan dengan lengkap seperti Nomor Induk Kependudukan, Nama Lengkap, Tanggal Lahir, nomor HP, hingga Alamat Lengkap Sesuai KTP.

4. Setelah isi data lengkap, pilih kantor imigrasi terdekat untuk pengurusan paspor Anda. Lalu, isi juga jumlah pemohon, tanggal dan waktu kedatangan. Ada dua pilihan Pagi (08:00 s/d 12:00) dan Siang (13:00 s/d 16:30) dan Anda akan melihat opsi pilihan kuota yang tersedia. Apabila

5. Kuota penuh, Anda harus mengganti hari dan pilih yang masih kosong yakni bertanda hijau.

6. Setelah semuanya proses selesai. Otomatis Anda akan mendapatkan Kode Booking (dalam bentuk serangkaian kode dan QR Code) serta informasi nomor antrian digital yang isinya informasi NIK, Nama,Tempat, Tanggal dan Waktu Anda datang ke kantor Imigrasi.

Setibanya di Kantor Imigrasi sesuai tanggal dan jam yang sudah ditentukan, anda tunjukan barcode ke petugas pintu masuk lalu diarahkan untuk cetak kartu antre. Kemudian ketika dipanggil, tinggal menyerahkan dokumen - dokumen yang telah ditentukan. Dokumen yang perlu dipersiapkan untuk untuk pembuatan paspor baru, antara lain:
a) KTP (e-KTP)
b) Kartu Keluarga
c) Akta Lahir/ijazah/Buku Nikah
d) Paspor Lama (bagi yang melakukan perpanjangan)

Selanjutkan anda akan dipanggil kembali untuk tahap wawancara .dan foto. Kemudian diminta untuk membayar. 
Berdasarkan hasil wawancara dan observasi diatas maka diketahui bahwa kantor imigrasi sudah memberikan penjelasan tentang tata cara dan arus pelayanan dalam pembuatan antrian paspor secara online dan menjelaskan tentang cara penggunaan apapo secara menyeluruh melalui costumers service, namun adapun kendala tentang kouta selalu penuh yang dikeluhkan oleh masyrakat dikarenkan suember daya manusia yang tebatas sehingga kantor imigrasi hanya memberikan kouta sebnyak 50 kouta penerbitan paspor setiap harinya.

\section{d. Sistem sosial}

Salah satu untuk mencapai keberhasilan inovasi yaitu sistem sosial, sistem soial masyarakat modren lebih mudah menerima inovasi dibandingkan dengan masyarakat yang berorientasi pada sisitem sosial tradisional karena masyarakat modren cendrung mempunyai sikap positif terhadap perubahan, umumnya menghargai terhadap pendidikan dan ilmu pengetahuan, mempunyai perspektif keluar yang lebih baik dan mudah berinteraksi dengan orang-orang di luar kelompoknya, sehingga mempermudah masukan penerima ide ide baru dalam sistem sosial.Sebagaimana yang dikatakan oleh masyarakat bapak ismail yang sudah menggunakan aplikasi apapo mengatakan:

"menurut saya, sangat membantu dengan adanya apapo ini karna kita tidak perlu mengantri lama lama lagi seperti tahun sebelumnya, tinggal pilih jadwal yang sesuai kita mau, jadi juga bisa membagai waktu dengan keperluan yang lain. harapan saya semoga aplikasi ini terus terjadi inovasi dan peningkatan"

Hal serupa juga kembali ditanyakan oleh ibu salmah selaku masyarakat yang menggunakan aplikasi apapo ini mengatakan bahwa :

"menurut saya, ada nya aplikasi apapo sangat membantu sekali , karna kita yang menentukan waktu kapan kita mau foto dan wawancara , tanpa harus mengantri seperti dulu, sekang ini enak banget karna pasti jadwal kita harus datang ke kantor imigrasi. harapan saya semoga aplikasi ini semangkin lebih bagus karna kan kita hidup di era milenial serba canggih."

Dalam inovasi pelayanan melalui aplikasi pendaftran antrian paspor secara online terdapat bnayak pengaruh sosial yang positif bagi masyrakat yang sibuk atau yang hanya memiliki waktu sedikit, sangat terbantu dengan adanya antrian permohonan paspor secara online seperti pekerja, pelajar, dan orang-orang yang mengerti tentang antrian permohonan paspor secara online. 
Adanya inovasi pelayanan antrian permohonan paspor secara online karena mengikuti pengaruh dari lingkungan sosial masyrakat. Masyarakat telah mengikuti perkembangan serta kemajuan dari teknologi komunikasi sehingga pihak imigrasi mengikuti kebutuhan dari masyrakat pelayanan publik. Sehingga bisa sejalan dengan masyarakat, dan masyrakat juga terbantu dan lebih nyaman, terutama bagi masyrakat yang rata-rata sudah menggunakan android tentu hal tersebut tidaklah sulit. Hal serupa juga kembali ditanyakan oleh ibu munati selaku masyarakat yang menggunakan aplikasi apapo ini mengatakan bahwa:

"menurut ibu dengan ada nya aplikasi apapo sangat membantu sekali, karna kita yang menentukan waktu kapan kita mau foto dan wawancara , tanpa harus mengantri seperti dulu, seperti saya saat saya ada pekerjaan dan saya bisa mengatur jadwal saya bekerja dengan pembuatan paspor ini. Harapan saya semoga aplikasi ini semangkin berkembang dan tumbuh inovasi- inovasi fitur nya sedhingga masyrakat mudah dalam mengakses aplikasi tersebut."

Berdasarkan uraian di atas, dengan adanya inovasi antrian permohonan paspor secara online merupakan hasil dari inovasi yang dilakukan pihak imigrasi untuk mempermudah, membantu, dan merupakan perwujudan untuk memenuhi kebutuhan dari masyrakat serta merupakan hasil dari pengaruh sistem sosial masyarakat yang menggunakan kemajuan teknologi komunikasi. Sehingga pihak imigrasi membuat aplikasi serta web yang dapat membantu masyrakat untuk mengakses serta mendaftar pada antrian permohonan paspor online, dan masyrakat juga memberikan harapan kedepannya agar aplikasi ini terus berinovasi.

\section{Kesimpulan}

Berdasarkan hasil penelitian maka dapat ditarik kesimpulan, bahwa inovasi pelayanan melalui aplikasi Apapo pada kantor imigrasi kelas I tanjungpinang sudah cukup berhasil, namun dari empat faktor keberhasilan inovasi yang di gunakan yaitu; karakteristik inovasi, saluran komunikasi, upaya dari agen dan sistem sosial. Terdapat dua indikator yang belum maksimal yaitu saluran komunikasi dan upaya dari agen.

1. Karakteristik inovasi 
Karakteristik dalam inovasi pelayanan melalui aplikasi APAPO pada kantor imigrasi kelas I tanjungpinang ini sudah tercapai dengan baik. berdasarkan tingkat keunggulan relatif pada suatu inovasi dapat diukur berdasarkan kesenangan, dan kepuasan, dan dapat dilihat dari jumlah pengunduh di playstore terdapat 1 juta lebih pengunduh, dan pada karakteristik inovasi ini sudah dirasakan dan dinilai positif oleh masyarakat terutama dalam kepastian waktu dalam pembuatan paspor.

2. Saluran komunikasi

Komunikasi dalam inovasi pelayanan melalui aplikasi APAPO pada kantor imigrasi kelas I tanjungpinang cukup baik dikarenakan pihak kantor imigrasi sudah memberikan sosialisasi aplikasi APAPO namun sosialisasi yang digunakan melalui media massa. Sosialisasi yang diberikan kepada masyarakat, diharapkan agar masyrakat mengetahui tata cara penggunaan APAPO namun masih banyak masyarakat yang tidak menggunakan media masa, sehingga masyarakat tidak mengetahui adanya aplikasi APAPO. dari pihak kantor imigrasi jugaa belum pernah mensosialisasi secara tatap muka kepada masyrakat.maka diketahui bahwa belum sepenuhnya menjalankan sosialisasi kepada masyrakat tentang penggunaan aplikasi apapo ini.

3. Upaya dari agen

Upaya peningkatan kualitas pelayanan keimigrasian terhadap masyarakat sudah cukup baik, Pihak kantor imigrasi selalu berusaha memberikan arahan terkait pendaftran antrian paspor secara online, apabila masyarakat atau pemohon bingung terkait mekanisme maka dapat lansung ditanyakan kepada petuagas (costumers service). dapat dilihat dari arus pelayanan pembuatan paspor ditunjukan dengan kemampuan petugas pelayanan imigrasi dalam mengelola kendalakendala yang terjadi dalam pelakasanaan APAPO sehingga permasalahan tersebut dapat diatasi dengan baik. Namun masih ada kendala yang dialami oleh masyarakat terhadap kouta yang terbatas, hal ini dikarenakan keterbatasan sumber daya manusia.

4. Sistem Sosial

Pada sistem sosial dalam inovasi pelayanan melalui aplikasi APAPO di kantor imigrasi kelas I tanjungpinang sudah baik dikarenakan 
masyarakat sekarang ini lebih menghargai perubahan yang dilakukan oleh kantor imigrasi karena mempunyai perspektif keluar yang lebih baik, sehingga mempermudah masukan penerima ide ide baru dalam sistem social, namun masih ada masyarakat yang justru merasa enggan untuk menggunkan aplikasi tersebut karena kurang familiar dalam menggunkan gadget.

\section{DAFTAR PUSTAKA}

Ayutasya, Putrika Isma, Dian Purwanti, and M. Rijal Amirulloh. 2020. "Implementasi Aplikasi Pendaftaran Antrian Permohonan Paspor Online." Jurnal Administrasi Publik 11 (1).

Chaharani, Nurrizha Ayu, Tri Putra Adi, and Diba Latifa Hasmi. 2020. "Penerapan Aplikasi Pendaftaran Antrian Paspor Online (Apapo) Dalam Perspektif E-Government." Jurnal Kebijakan Publik 11 (2)

Delafrooz, Narges, Mohammad Taleghani, and Mahsa Taghineghad. 2013. "The Impact of Service Innovation on Consumer Satisfaction." International Journal of Marketing and Technology 3 (5)

Hutagalung, Simon Sumanjoyo, and Dedy Hermawan. 2018. Membangun Inovasi Pemerintah Daerah. Deepublish.

Mirnasari, Rina Mei, and F Suaedi. 2013. "Inovasi Pelayanan Publik UPTD Terminal Purabaya-Bungurasih." Kebijakan Dan Manajemen Publik 1 (1)

Said, M Mas' ud. 2007. Birokrasi Di Negara Birokratis: Makna, Masalah, Dan Dekonstruksi Birokrasi Indonesia. UMM Press.

Sentosa, Joko Imam. 2019. "Efektivitas Implementasi Program Inovasi Peserta Pendidikan Dan Pelatihan Kepemimpinan Tingkat Iii Di Badan Pengembangan Sumber Daya Manusia Provinsi Sumatera Selatan." Jurnal Sumber Daya Aparatur 1 (2).

Sugiyono, Sugiyono. 2010. "Metode Penelitian Kuantitatif Dan Kualitatif Dan R\&D." Alfabeta Bandung.

Suryani, Meti, and Fitria Yuliani. 2020. "Kendala Inovasi Media Dalam Pembuatan Paspor Di Kantor Imigrasi Kelas I Tpi Bengkulu." Jurnal Sarjana IImu Komunikasi 1 (1): 1-9. https://doi.org/10.36085/j-sikom.v1i1.774.

Susanto. 2010. Management Gems. Jakarta: Kompas.

Sutarno. 2012. "Serba-Serbi Manajemen Bisnis." Yogyakarta: Graha I/mu.

Wilonotomo; Koesmoyo Ponco Aji. 2018. "Pelayanan Pembuatan Paspor Dalam Kajiannya Terhadap Teori Manfaat Teknologi Informasi." Jurnal Ilmiah Kebijakan Hukum 12 (1) 